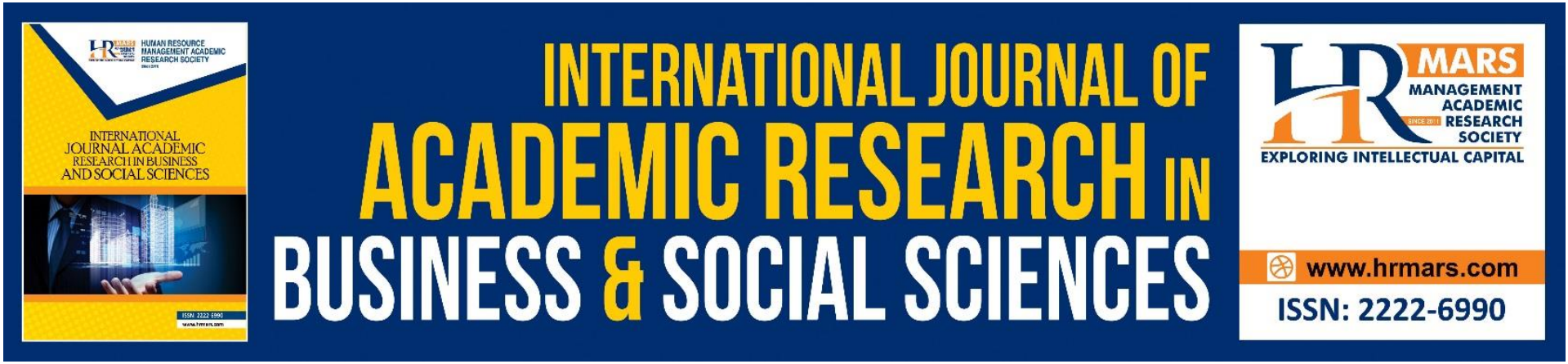

\title{
Language Error from Western Scholar Perspectives
}

\author{
Abdul Hamid Moiden, Jessica Ong Hai Liaw
}

To Link this Article: http://dx.doi.org/10.6007/IJARBSS/v11-i3/8993

DOI:10.6007/IJARBSS/v11-i3/8993

Received: 01 January 2021, Revised: 30 January 2021, Accepted: 20 February 2021

Published Online: 19 March 2021

In-Text Citation: (Moiden \& Liaw, 2021)

To Cite this Article: Moiden, A. H., \& Liaw, J. O. H. (2021). Language Error from Western Scholar Perspectives. International Journal of Academic Research in Business and Social Sciences, 11(3), 957-966.

Copyright: (C) 2021 The Author(s)

Published by Human Resource Management Academic Research Society (www.hrmars.com)

This article is published under the Creative Commons Attribution (CC BY 4.0) license. Anyone may reproduce, distribute, translate and create derivative works of this article (for both commercial and non-commercial purposes), subject to full attribution to the original publication and authors. The full terms of this license may be seen at: http://creativecommons.org/licences/by/4.0/legalcode

Vol. 11, No. 3, 2021, Pg. 957 - 966

http://hrmars.com/index.php/pages/detail/IJARBSS

JOURNAL HOMEPAGE

Full Terms \& Conditions of access and use can be found at http://hrmars.com/index.php/pages/detail/publication-ethics 


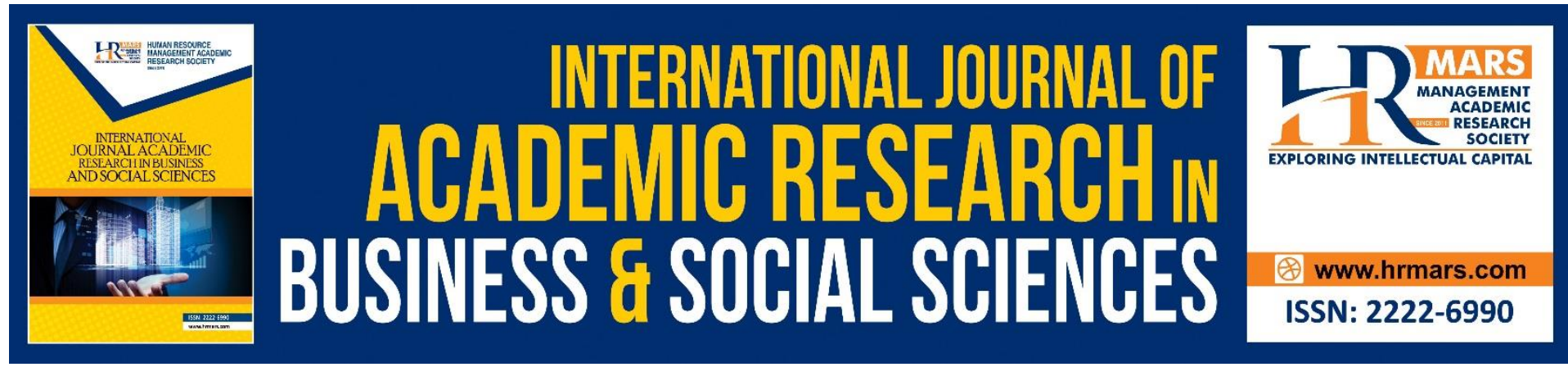

\title{
Language Error from Western Scholar Perspectives
}

\author{
Abdul Hamid Moiden, Jessica Ong Hai Liaw \\ Faculty of Defence Studies and Management, National Defence University of Malaysia, \\ 57000 Kuala Lumpur \\ Email: abdulhamied6@gmail.com
}

\begin{abstract}
This study examined the concept of language error from the perspective of Western scholars. The design of this study was the content analysis approach. Document analysis methods explained the views of Western scholars. Language teaching and learning are critical in schools and higher learning institutions globally. Humans communicate orally and in writing by making language an intermediary medium. Relevant use of language according to the situation will promote the understanding of the listener or reader. Incompetent language use includes several language mistakes and induces constraints in reading a message in detail. Language error and language mistakes are two phrases that language scholars extensively discuss. The conclusions of the study confirmed that first language speakers and second language speakers perform language errors Additionally, the study outcomes indicated that language error in writing or speech is inevitable by first and second language speakers. The summaries also revealed that language error could be overcome through language teaching and learning in an arranged and methodical practices.
\end{abstract}

Keywords: language Error, Scholars, Incompetent, Teaching, Learning.

\section{Introduction}

Language is an imperative mechanism of human interaction. This communication tool is unique because it has a precisely organised system and pattern. Languages grow over time. It prompts language to continually evolving with the advancement of science and technology. Language error and language mistakes are two phrases that language scholars extensively discuss. The Fourth Edition of the Institute of Language and Literature Dictionary defined 'Salah' (error) as untrue, incorrect, inaccurate, inexact, inappropriate and wrong, and established 'Silap' (mistake), as not understanding what is real, unintentional mistakes, misinterpretation or confusion. Every language user, whether native or non-native speakers, cannot avoid language errors and mistakes.

Language errors imply competence error. This error happens due to the speaker or writer's weakness because they cannot master the language's formulas correctly. Language errors are known as performance errors influenced by the writer's physical factors such as fatigue, drowsiness, forgetfulness, emotional stress and hastening to complete a task. This 
error does not transpire because they do not know the rules of the language. Performance errors are also known as an 'a slip of the tongue'. Physical or emotional disorders prompt these mistakes.

Western scholars such as Corder, Ellis and Selinker discussed language errors from individual perceptions. Linguists employ these three scholars' opinions on language education. In higher learning institutions, these scholars' opinions are incorporated into the teaching syllabus and acknowledged theoretically and scientifically.

Language errors occur in the areas of phonology, morphology, syntax, discourse and semantics. Language errors also stem from the influence of the first language (B1) into the second language (B2). Language errors are also caused by violations of grammatical formulas. The structural differences of the first language (B1) with the second language (B2) influence this error. In addition, language errors also stem from the inversion of B1 in B2. Language errors stem from teacher factors, teaching methods, learning strategies, selection of teaching materials, attitudes and motivation of students when learning the language. Error analysis helps categorize language errors into linguistic, psychological aspects (ability and appearance errors), sources of errors (interlingual and intralingual) and the effects of errors on communication (oral and written communication). Based on Brown (2000) and Richards (1992) asserted that language errors occur as a result of differences between the original language and the target language of the student, extreme generalizations, misconceptions and other factors. According to Maicusi et. al. (2000), language errors stem from psycholinguistic, sociolinguistic and epistemic factors.

Hence, the objective of this study as follows

- To determine the concept of language error from the perspective of Western scholars

- To determine incompetent language use includes several language mistakes and induces constraints in reading a message in detail

\section{Research Concept of Language Errors from Western Scholar Perspective Ellis}

Professor Rod Ellis is a well-known linguist in the field of second language acquisition studies. Professor Ellis earned a Master of Education from the University of Bristol and continued his Doctor of Philosophy studies at the University of London. He has served as a professor in England, Japan, the United States, Zambia, Australia and New Zealand. The University of Auckland once appointed him as Director of the Institute of Language Teaching and Learning. He has won the Oxford University Duke of Edinburgh Award for his study entitled 'Study of Second Language Acquisition'. Besides, he has also composed various textbooks and references for Prentice Hall and Oxford University Press publishers. His essays such as 'First Steps in Reading: A Teacher's Handbook for Using Starter Readers in the Primary School', 'Learning a Second Language Through Interaction', 'The Study of Second Language Acquisition', 'First Steps in Reading: A Teacher's Handbook for Using Starter Readers in the Primary School', is used as the leading textbook in most universities in acquisition and grammar domains of the second language for TESL and linguistic programs.

Ellis (1997) revealed that student errors could help language teachers or researchers from time to time. He explained, 
"Classifying errors in these ways can help us to diagnose learners' learning problems at any stage of their development and to plot how changes in error patterns occur over time."

Pit Corder introduced language Error Analysis. The results of the Corder discovery are still relevant to this day. Corder Language Error Analysis has inspired language researchers to attend out-and-out researches in language subjects, including Ellis. Ellis (1994) defined the contribution of Corder as,

"It was not until the 1970s that EA became a recognised part of applied linguistics, a development that owed much to the work of Corder."

Ellis (1997) distinguished errors and mistakes through two methods. The first method is to check student performance from one level to another continuously. If a student's language is not balanced and sometimes uses the right and wrong language intermittently, they make a mistake. Nevertheless, if a student repeats the same language error, the student commits a language error. The second method is to instruct students to identify and correct their errors. If the student manages to identify the errors and correct them, the student makes a mistake. If the student fails to correct his errors, the student commits a language error.

Other second language learning readings showed that second language learners commit many morphological and syntactic errors (Ellis, 1997). Morphology and syntax are the two chief divisions of the language besides semantics and phonology.

Ellis (1985) proposed five steps to analyse language errors as follows;
a) Collect sample errors
b) Identify the errors
c) Explain the error
d) Classify the errors
e) Assess the errors

Ellis (2008) classified language errors into 'omission', 'misinformation' and 'misordering'. An omission error transpires when a student omits the central part of a sentence until it becomes ungrammatical. Misinformation error implies a misuse of word forms. The misordering error suggests the placement of words in the wrong order.

Ellis (1997) described that 'error' and 'mistake' are entirely distinctive. According to him, errors represent students' language knowledge because they fail to understand a language concept. 'Mistake' only happens once and may occur due to student negligence.

\section{Corder}

Stephen Pit Corder was born on October 6, 1918. He died on January 27, 1990. Pit Corder was a professor of applied linguistics at the University of Edinburg, Scotland. He was a linguist. He played a key role in the development of applied linguistic studies in England.

Pit Corder began his early education at Bootham School, a boarding school. His father was an English teacher. He continued his studies at Merton College in Oxford. Later, Corder 
continued his studies at the Great Ayton Friends school. Corder has served for the British Council in Austria, Turkey, Jamaica and Colombia. Apart from teaching, he also designed the syllabus and prepared teaching materials. In 1957, Corder continued his diploma studies at the University of Edinburgh in applied linguistics to meet the British Council's demands. The British Council intended to use Corder expertise for the development of English language teaching and learning worldwide. Upon graduation, Corder was sent to Nigeria to develop English teaching materials for Nigerian television stations.

Pit Corder has delivered several copies of linguistic books and language errors. To date, among his books that are the principal reference for linguists are;

'An intermediate English Practice Book', 'The Significance of Learner's, 'Error Analysis and Interlanguage'.

Corder was the Director of the School of Applied Linguistics at the University of Edinburgh. One of Corder's most outstanding contributions was establishing the Department of Applied Linguistics at the University of Edinburg in 1964. Corder completed his professional career at the University of Edinburg.

Corder (1972) related Language Error Analysis as;

"Dealing with the differences between the way people learning a language speaks and the way adult native speakers of the language use the language".

Pit Corder, in his book 'Error Analysis and Interlanguage' proposed the idea of learning a second language and a foreign language is something that is continuously evolving. This development is evident by analysing the mistakes made by students from time to time. This error represents a sign of positive language growth rather than a flaw (Corder, 1981) Selinker successfully formed this idea in 1972 by proposing the notion of 'Interlanguage'.

Corder (1967) demonstrated that mistakes are inherent to educators, students and linguists. Educators can measure and evaluate the development of student performance during the learning process. Language researchers can analyse the means of language acquisition and strategies used by students when learning a language. Students who learn the language can determine their language errors and learn from them.

Transfer errors are closely associated with native language disorders. Corder (1971) affirmed that native language disorders happen when language habits such as language forms, language systems or first language rule of the students interfere or prevent them from acquiring forms, systems or rule in a second language.

According to Corder (1973), categories in errors in second language learning are;

a) elimination of necessary elements

b) addition of unnecessary or inaccurate elements

c) incorrect selection elements

d) incorrect arrangement of elements 
Nonetheless, Corder (1981) also added morphological, syntactic and lexical errors in second language learning.

According to Corder (1981), the five steps of Language Error Analysis are;

a) collect the language errors

b) identify the language errors

c) describe the language errors

d) explain the language errors

e) evaluate/correct the language

Pit Corder (1967) introduced six inherent concepts that form the framework of Error Analysis Theory. Some of the concepts are acquiring a second language, the influence of the development of the mother tongue (first language), the level of proficiency of students as a whole, intralingual and interlingual factors, and the creative formation process interlanguage, and system in interlanguage.

Predominantly, Corder (1981) described language mistakes as forms of speech that deviate or contradict the speech forms of native speakers. Language mistakes are a form of language use that deviates from the language system accepted as standard by educated native speakers. These mistakes incorporate aspects of grammar, spelling, words use, and terms.

Pit Corder founded the Theory of Language Error Analysis. This theory examines the language error made by a person. Language errors are a form of language use that deviates from the standard language system. Language errors include grammatical errors, spelling, pronunciation and terminology. Corder (1981) divided language errors into mistakes, lapses and errors.

'Lapses' is a deviation in the use of language that occurs due to the shift in the topic of the speaker's discussion because the speaker changes the way he or she expresses something before the whole sentence is stated fully. This error in the oral language is known as an 'a slip of the tongue'. This error transpires accidentally, and the language user is unaware of the mistake. 'Mistake' is a deviation in language use because the user does not use the language correctly when speaking or writing according to the circumstances. This error is not due to the user not mastering the second language. 'Error' is a deviation from the use of language from the standard structure because the user has not mastered the grammar. Furthermore, 'error' occurs when a proficient speaker comprehends the first language's grammar and uses the second language's grammar rules.

\section{Selinker}

Larry Selinker is Professor Emeritus in the linguistics of the University of Michigan in the United States. He previously held the position of Director of the English Language Institute at the university. In 1972, Selinker introduced the concept of 'Interlanguage'. This concept was formed based on the concept of language error analysis in second language acquisition, which Pit Corder introduced with a Bachelor of Arts degree from Brandeis University in the field of Near-Eastern studies. In 1960, he earned a Master's Degree from the American University in linguistics. In 1966, Selinker received his Doctor of Philosophy Degree from Georgetown University, USA. 
Following graduating with a Doctor of Philosophy degree, Selinker was offered an assistant professor in linguistics at the University of Washington. In addition to holding the position of Director of English, he also taught English to international students at the University of Washington. From 1968 to 1969, he was appointed as Fulbright Scholar at Edinburgh University in second language acquisition psycholinguistics. In 1975, he received a Fulbright scholarship to continue his studies at the University of Jerusalem, specialising in second language studies. Selinker completed his academic career at the University of Michigan in 1993.

Selinker's principal contribution to second language acquisition research is the concept of 'Interlanguage'. He proposed the concept of Interlanguage'in 1972 by presenting a paper based on the Pit Corder article entitled, 'The Significance of Learners' Errors'. Although this paper was the essential basis of his writing, Selinker managed to present some novel language acquisition arguments. Interlanguage emerges from Mistake Analysis and Contrastive Analysis, which fails to explain second language mistake comprehensively, systematically and absolutely. (Al-Khresheh, 2015; Princess Roslina, 1996 \& 2004; Selinker, 1972; Tarone, 2006).

Selinker (1969) maintained that 'Interlanguage' is a language system produced from the acquisition of a second language by an adult speaker due to an attempt to convey meaning in the language they are learning. Interlanguage refers to the first language of the speaker and not the second language of the speaker. Interlanguage is produced from the process of processing a speaker's second language. Interlanguage language belongs to the disciplines of Applied Linguistics, and it is critical in the study of second language acquisition since this concept was introduced by Selinker (Song, 2012). According to Tarone (2006), interlanguage plays an indispensable position in developing second language acquisition research.

Selinker (1972) listed five conditions that result in language errors. These conditions are;

a) Language transfer. This error occurs due to the transfer of the elements of the first language into the second language.

b) Transfer of training. This error happens due to incorrect language learning methods.

c) Strategies of second-language learning. This error is due to an incorrect second language strategy.

d) Strategies of second-language communication. Language errors made by language learners who communicate with native speakers.

e) Overgeneralisation. This error takes place due to the generalisation of the target language method used excessively.

\section{Jack C. Richards}

Dr. Richard was born in New Zealand. In 1966, he was awarded a Master of Arts Degree with first class honors in English from Victoria University in Wellington, New Zealand. Subsequently, he graduated with a Doctor of Philosophy degree in Applied Linguistics from Laval University (French University) in Quebec City, Canada in 1972. 
He has served in New Zealand, Canada, Indonesia, Singapore, Hong Kong, and the United States. After completing his PhD, he taught in Indonesia and was later appointed as an applied linguist at the Singapore Regional Language Center, under the New Zealand Government.

He was later appointed Senior Lecturer of English at the Chinese University of Hong Kong and in 1981 took up the position of professor in the Department of English as a Second Language at the University of Hawaii. In 1999, Dr. Richards retired and began concentrating on teaching short -term courses and conducting workshops in several countries including the Regional Language Center (RELC), Singapore and the University of Sydney, appointing him as an honorary professor.

Language Error Analysis examines interlingual errors and intralingual errors that stem from specific teaching and learning strategies. (Richard, 1971). According to Richard (1974) transfer or 'interlingual' errors stem from native language disorders. According to him, the disruption of the mother tongue in terms of form, system and law prevents students from acquiring the form of the system and law of the second language. According to Richard (1992) interlingual errors are due to errors that occur during language transfer that are influenced by the first language. Based on Richards, Platt, Weber and Candlin (1992), the factors that motivate students to perform when writing or speaking are due to lack of concentration, fatigue or carelessness.

Error Analysis does not deny the role played by the first language in the existence of language errors. First language disorders account for only 33 percent of language errors committed by second language learners. This is confirmed by Richards (1971) as, "George (1972) found that one third of the deviant sentences from second language learners could be attributed to language transfer". The 'intralingual' errors of second language learners are based on "partial exposure to the target language" (Richards, 1974).

Richards (1971) divides language errors into three categories, namely interlanguage errors, evolving errors and errors in language. Errors in language are due to the process of extreme generalization with the target language, ignorance of language rules, imperfect use of language rules as well as making wrong assumptions about language concepts.

Richards and Sampson (1974) have listed seven factors that can influence students in learning a foreign language or a second language, namely language transfer, intralingua, sociolinguistic situation. ), intermediate (modality), age, successions of approximate systems and universal hierarchy of difficulties. Richards also divided the cause of the offense into three parts. First, interlingual errors caused by interlingual errors (Richards 1974). Second, errors in one language (intralingual errors) caused by faulty generalization, incomplete application of rules, failure to learn conditions under which rules apply. Third, developmental errors caused by extreme generalizations, ignorance of rule restriction, imperfect implementation of language rules and false concepts hypothesized (Richards 1974).

According to Richards (1978) linguistic error as a deviation from the norm found in utterance as a result of proximity to the first language. To find the mistakes or the process of mistakes that students make in learning and using the target language. Through the analysis 
of language errors will be obtained an overview of the development of one's language. To that end, the analysis of language errors is one part of the psycholinguistics of language learning.

\section{Conclusion}

Ergo, it is evident that the scholars Ellis, Corder, Selinker and Jack confirmed that language errors are unavoidable in language learning. Several determinants affect the language errors of native and non-native speakers. The errors made by first and second language speakers are not identical even though they appear similar Nevertheless, language errors and the method of language error analysis submitted by these four scholars are diverse. Therefore, language errors in speech and writing have driven more scientific investigations and discoveries that promote language education. Besides, this study can be extended by categorize the common language errors used in teaching and learning based on the origin of native speaker. Currently, we are collecting information and conducted extensive literature review analysis, and shall reporting it in subsequent publication.

\section{References}

Al-Khresheh, M. H. (2015). A Review Study of Interlanguage Theory. International Journal of Applied Linguistics \& English Literature, 4(3), 123-131.

Brown, H. D. (2000). Principles of Language Learning and Teaching. New York: Longman.

Corder, S. P. (1967). The Significance of Learner's Errors. IRAL-International Review of Applied Linguistics in Language Teaching, 5(1-4), 161-170.

Corder, S. P. (1971). Idiosyncratic Dialects and Error Analysis. IRAL- International Review of Applied Linguistics in Language Teaching, 9(2), 147-159.

Corder, S. P. (1973). Introducing Applied Linguistics. Baltimore: Penguin Education.

Corder, S. P. (1981). Error Analysis and Interlanguage. Oxford University Press.

Corder, S.P. (1983). Strategies of Communication. In C. Faerch \& G. Kasper (Eds), Strategies in Interlanguage Communication (pp. 15-19). London: Longman.

Corder, S.P. (1987). Error Analysis and Interlanguage. Oxford, Oxford University Press.

Corder, S. P. (1981). Error Analysis and Interlanguage. London: University Press.

Corder. S. Pit. (1981). Error Analysis and Interlanguage. London: University Press

Ellis, R. (1985). The L1 = L2 Hypothesis: A consideration. System, 13(9), 9-24.

Ellis, R. (1994). The Study of Second Language Acquisition. Oxford: Oxford University Press

Ellis, R. (1997). SLA Research and Language Teaching. Oxford: Oxford University Press.

Ellis, R. (2008). The Study of Second Language Acquisition (2nd ed.). Oxford: Oxford University Press.

Jack, C. R., \& Gloria, P. S. (1974). The Study of Learner English, in Jack C. Richards (ed.), Error Analysis: Perspectives on Second Language Acquisition, pp. 3-18. London: Longman Group Ltd.

Maicusi, T., Maicusi, P., \& Lopez, M. J. C. (2000). The Error in the Second Language Acquisition. Encuento Revista de Investigacion Innovacion en la Clase de Idiomas, 11, pp. 168-173.

Richard, J. (1978). Error Analysis: Perspectives on Second Language. London: Longman Group Limited.

Richards, J. C. (1971). A Non-Contrastive Approach to Error Analysis. Richards, J.C. (ed). Error Analysis. London: Longman.

Richards, J. C. (editor) (1974). Error Analysis: Perspectives on Second Language Acquisition. London: Longman. 
Jack, C., Richards., \& Gloria, P. S. (1974). The Study of Learner English, in. Jack C. Richards (ed.), Error Analysis: Perspectives on Second Language Acquisition, pp. 3-18. London: Longman Group Ltd.

Richards, J. C., Platt, J. T., Weber, H., \& Candlin C. N. (1992). Longman Dictionary of Applied Linguistics. Essex: Longman.

Selinker, L. (1969). Language Transfer. General linguistics, 9(2), 67.

Selinker, L. (1972). Interlanguage. IRAL-International Review of Applied Linguistics in Language Teaching, 10(1-4), 209-232.

Selinker, L. (1972). Interlanguage. IRAL-International Review of Applied Linguistics in Language Teaching, 10(1-4), 209-232.

Song, L. (2012). On the Variability of Interlanguage. Theory and Practice in Language Studies, 2(4), 778- 783.

Tarone, E. (1983). On the Variability of Interlanguage System. Applied Linguistics, 4(2), 143163.

Tarone, E. (2006). Interlanguage. In K. Brown (Ed.), Encyclopedia of Language and Linguistics (2nd ed.), 5, (pp. 747-752). Oxford: Elsevier. 